\title{
KRZYSZTOF GOMBIN
}

\section{O REMINISCENCJACH KONFLIKTU O ORDYNACJE OSTROGSKA W SZTUCE KRĘGU JANA KLEMENSA BRANICKIEGO}

Rzeźba z klatki schodowej białostockiego pałacu Jana Klemensa Branickiego, najczęściej określana jako Rotator, czyli „Obracający się”, albo Arrotino, czyli „Ostrzący nóż”, wzbudzała zainteresowanie kilku pokoleń badaczy'. Ustawiona na piaskowcowym postumencie, wykonana $z$ białego marmuru przedstawia niemal całkiem nagiego (jedynie z przerzuconą przez prawe ramię udrapowaną szatą), klęczącego na prawym kolanie mężczyznę, o uniesionej i mocno odwróconej w lewo głowie oraz skierowanym ku górze wzroku. Postać, zgodnie z tradycyjnie przypisanym mianem, ostrzy na kamiennej osełce płaski nóż. Dzieło jest swobodną kopią antycznego marmuru (i to nie wzbudza dziś wątpliwości), przechowywanego obecnie we florenckiej Galerii Ufizzi (Oleńska, „Sekretne treści” 645). Brakuje natomiast communis opinio, jeśli chodzi o ukryty przekaz białostockiej rzeźby.

Anna Oleńska wskazała na związki między zamówieniem przez Branickiego Rotatora a sprawą ordynacji ostrogskiej („Wątki heroiczne” 260; „Sekretne treści” 643-655; Jan Klemens Branicki 309-320). Wyrzeźbiona przez Jana Chryzostoma Redlera i ustawiona w westybulu białostockiego pałacu na jesieni 1755 r. praca, miała przedstawiać jednego z rzymskich bohaterów (Windycjusza, Milichusa, czy też Feniusza Rufusa), który podczas wykonywania swojej pracy podsłuchał spiskowców i tym samym udaremnił ich knowania. Miała to być aluzja do roli hetmana we współczesnych mu wydarzeniach (Oleńska, Jan Klemens Branicki 317).

Dr hab. KRZYSzTOF GomBIN - Katedra Historii Sztuki Średniowiecznej i Nowożytnej, Instytut Nauk o Sztuce, Katolicki Uniwersytet Lubelski Jana Pawła II; adres do korespondencji: Al. Racławickie 14, 20-950 Lublin; e-mail: kgombin@vp.pl; ORCID: https://orcid.org/0000-0002-0097-2518.

${ }^{1}$ Szczegółowy stan badań przedstawia Anna Oleńska (,Sekretne treści” 643-655). 
Trafne wnioski Oleńskiej oparte zostały jednak na stosunkowo skąpej bazie źródłowej. Spotkały się także z krytyką Tomasza Dziubeckiego, który zaproponował własną, odmienną od Oleńskiej, interpretację tej rzeźby, sugerując, że może być to służący Apolla szykujący nóż, którym bóg ma ukarać Marsjasza (Dziubecki, „Rotator” 657-660 i Programy symboliczne passim). Temat wydaje się więc wart ponownego zainteresowania.

W połowie XVIII wieku Rzecząpospolitą wstrząsnęła sprawa ordynacji ostrogskiej. Utworzona przez księcia Janusza Ostrogskiego w 1609 r., złożona z 21 miast i blisko 600 wsi, była największą ordynacją w Koronie. Na początku lat pięćdziesiątych znajdowała się we władaniu marszałka nadwornego litewskiego Janusza Sanguszki, który mając długi, rozdzielił ją (bez zgody sejmu) pomiędzy 34 wierzycieli, na mocy układu zawartego w Kolbuszowej 7 grudnia 1753 r. Największymi beneficjentami podziału stali się Lubomirscy, natomiast główny ciężar odporu ataków przeciwników wziął na siebie wojewoda ruski August Aleksander Czartoryski. Do transakcji kolbuszowskiej wrogo nastawiona była większość opinii szlacheckiej, uznając, iż jest to pogwałcenie praw obowiązujących w Rzeczypospolitej. Głównym przeciwnikiem podziału okazał się hetman wielki koronny Jan Klemens Branicki. Branicki już w lutym 1754 r. zajął Dubno (główną siedzibą Janusza Sanguszki). Tłumaczono to względami bezpieczeństwa, gdyż ordynacja miała obowiązek wystawić 600 żołnierzy do obrony granic Rzeczypospolitej, czego po podziale nie czyniła. August III reskryptem z 2 września $1755 \mathrm{r}$. przekreślił układ kolbuszowski i powołał komisję mającą zlustrować dobra, zwaną komisją dubieńską. 10 maja 1758 r. mocą reskryptu królewskiego dobra powróciły do Janusza Sanguszki, bez możliwości ich zbycia. W roku 1766 sejm uznał je za zwyczajne dobra ziemskie, czyli podlegające parcelacji ${ }^{2}$.

Anna Oleńska cytując w pracach o Branickim, wydane drukiem, pamiętniki Marcina Matuszewicza i Jędrzeja Kitowicza wskazała, że hetman był: „Stróżem najczulszym całości dóbr Rzeczypospolitej” (Kitowicz) powodowany „miłością prawdziwą dla ojczyzny i nie interesowną ku dobru publicznemu żarliwością" (Matuszewicz) (Oleńska, Jan Klemens Branicki 317; Kitowicz, Pamiętniki 71; Matuszewicz, Diariusz życia mego 437).

W świetle niepublikowanych źródeł można do tego dodać jeszcze inne, ale bardzo istotne wątki, pozwalające lepiej rozumieć ikonografię z kręgu fundacji

${ }^{2} \mathrm{Z}$ syntetycznych opracowań dotyczących dziejów konfliktu o ordynację ostrogską aktualne pozostają teksty Władysława Konopczyńskiego, zwłaszcza: „Ostrogska ordynacja” 793-797 oraz Polska $w$ dobie wojny siedmioletniej t. 1 passim. Z relacji pamiętnikarskich natomiast na uwagę zasługują: Matuszewicz, Diariusz życia mego t. 1 428-450; Kitowicz, Pamiętniki 70-72. 
Jana Klemensa Branickiego. Hetman jest jednym z głównych bohaterów dwóch utworów satyrycznych powstałych w związku ze sporem o ordynację, a pisząc bardziej precyzyjnie, dwóch wariantów tego samego utworu. Wersja bardziej znana i znacznie częściej w XVIII wieku rozpowszechniana nosi tytuł Łysa rada kolbuszowska. O jej popularności świadczy liczba zachowanych do dnia dzisiejszego odpisów. Paulina Buchwald-Pelcowa w swej pionierskiej pracy o satyrze polskiej czasów saskich podaje dziewięć rękopiśmiennych kopii (Buchwald-Pelcowa 193). Do tego można dodać jeszcze przynajmniej dwie ${ }^{3}$. Drugi tekst to: Scena tragiczno-komiczna na publicznym światu polskiego theatrum pokazana wyrok niewinnej śmierci i cudownego po tym uwolnienie ordynacyi ostrogskiej prezentujaca Ojczysta Muza przez jednego ze spektatorów opisana , w nim to w sposób bardziej dobitny zaakcentowana została rola hetmana wielkiego koronnego w opisywanych wydarzeniach. Ze zrozumiałych względów ten ostatni tekst będzie podstawą niniejszych rozważań.

W Scenie tragiczno-komicznej transakcja kolbuszowska przedstawiona została jako spisek przeciwko Patrii - Rzeczypospolitej, która przestrzegana jest przez Famę:

Co czynisz matko wolnego Narodu,

Lechia patrz o to śmierć już z krwi twej płodu, Zbliżają na cię już zdrady już spiski,

Prywatne przeciw tobie knują zyski [...]

Właśni synowie Twoi tak odrodni,

Stali się że już gotowi do zbrodni.

Już się spisali, już Se hasło dają,

Kiedy y jak część twą rozszarpać mają.

Sprawa nie jest jednak wcale z góry przegrana, gdyż jak głosi Fama, są w Rzeczypospolitej jej godni obrońcy:

Jeszcze to może inaczej się stanie,

Nie jest wszak prawem kilku osób zdanie,

${ }^{3}$ Archiwum Główne Akt Dawnych (AGAD), Zbiór Anny z Potockich Ksawerowej Branickiej, sygn. 469, Łysa rada kolbuszowska, k. 81 n.; Biblioteka Poznańskiego Towarzystwa Przyjaciół Nauk, rkps 360, Łysa rada kolbuszowska. Dialog satyryczny wierszem w sprawie ordynacji ostrogskiej, rozwiązanej przez Janusza Aleksandra Sanguszkę..

${ }^{4}$ Biblioteka Jagiellońska, rkps 1808 IV. Scena tragiczno-komiczna na publicznym światu polskiego theatrum pokazana wyrok niewinnej śmierci i cudownego po tym uwolnienie ordynacyi ostrogskiej prezentująca Ojczysta Muza przez jednego ze spektatorów opisana. Wszystkie cytaty w niniejszym tekście pochodzą z tego rękopisu. 
Ani też skutku pociąga za sobą, Dla wszystkich, co kto swoje chce osobą, Masz bowiem synów kochających wielu, Z których Branicki wybrany na celu, Stawi się hetman jako czuły granic, Stróż swoich, więc te wszystkie spiski za nic.

Po tym jak, „spiskowcy” wpisali transakcję do akt sandomierskich, tym samym ostatecznie ją zatwierdzając, Hetman o całej sprawie dowiaduje się od echa:

Liczą awantaż za dekret na zgubę

Ordynacji y już w tym swą chlubę

Sandomirskimi zatwierdzą aktami

Członki ojczyzny jak szarpią sztukami

O czym gdy da się słyszeć Hetmanowi,

Baśnią rzecz sądzi nie wierząc echowi

Tak okropnemi rozumie żeby ta

Myśl w wielkich Ludziach niebyła użyta

Gdy jednak lepiej upewniony po tym

Musi już wierzyć lecz rozumie o tym

Z wolna traktując chce ciało Ojczyzny

Od rąk Braterskich tej obronić blizny.

Kolejny istotny wątek zaznaczony w Scenie tragiczno-komicznej dotyczy faktu zastępowania przez hetmana Augusta III, pod nieobecność którego Branicki staje się faktycznie najważniejszą osobą w Rzeczypospolitej i jej mężem opatrznościowym:

Gdy w Państwie nie masz przytomności Pana

Zgiełk, gwałt ratunku żebrzą u Hetmana.

Przeto roztropnie wódz z senatem całym

Zniosły się naprzód umysłem wspaniałym

Idzie w kontr temu, edykt wojsku daje

Zajechać Dubno, tak się zaraz staje.

Chociaż sprawa zajazdu na Dubno nie była jednoznaczna pod względem prawnym $^{5}$, w satyrze przedstawiona została jako niekwestionowana zasługa Hetmana.

${ }^{5}$ Tak na przykład wojewoda smoleński Paweł Sapieha 22 III 1754 (a więc w miesiąc po zajęciu Dubna) o stronniku Branickiego Antonim Potockim pisał do strażnika koronnego Stanisława Lubomirskiego: „Wojewoda bełski tu dziś stanął był u mnie chorego w dyskursie o tej ordynacji bardzo 
Zajęcie Dubna powoduje kolejne knowania spiskowców. Tym razem Hetmanowi donosi o nich sama Ojczyzna. Branicki zasłyszane informacje przekazuje królowi, który w międzyczasie zdążył wrócić do kraju:

Jeszcze nie koniec skrytej niby Radzie

A już Ojczyzna wiadoma o zdradzie.

Myśli jak z złymi ma przystąpić syny

Więc wodzowi te doniosłszy nowiny

Skarży się Ojcu Ojczyzny Polaków

Jak gorliwych ma kraju swym Jonaków

Zanosi raport co ma być w Piotrkowie

Iż rękę podnieść chcą na Braci Zdrowie

Jak się armuią y cokolwiek sława,

Przynosi Hetman pod sąd Panu dawa.

Nie wiem jak mówić Miłościwy Panie

Fałsz czyli prawda ludzkie ma szemranie

Że kupy jakieś pod Piotrków ściągają

Skąd? Po co nie wiem to tylko gadają.

Iż na Trybunał przyszły się gromadzą

I' Już po traktach z wojskami się wadzą

Przyczyną opisywanych zamieszek był oczywiście konflikt o ordynację, gdyż jak wyjaśniał hetman królowi:

Sprawa Dubieńska śmiałości tej celem Jest w pretendentach ze zdradnym fortelem

Nie prawna sobie ten Jej koniec żwawy

Domowe zacząc w Ojczyźnie rozruchy

Chcą w łaski Pańskie trzymając otuchy.

August III w pełni poparł racje Branickiego:

Zażyjże swego więc Wielki Hetmanie

Prawa na prawa ordynując na nie

Wojsko, a jeżeli większej by trza mocy

Przydam y Sasów moich do pomocy.

Warto w tym miejscu dodać, iż na wiosnę 1754 r. chyba istotnie doszło w Wielkopolsce do pewnych rozruchów. Paweł Sapieha, będąc regimentarzem wielkopolskim, w marcu tegoż roku pisał do strażnika koronnego Stanisława

ozięble ze mną mówił, ale widzę że po części wstydzą się, co zrobili” (AGAD, Archiwum Potockich z Łańcuta, (APzŁ) sygn. 1833, s. 2. Por. Szwaciński 37). 
Lubomirskiego: „Odebrawszy ordynanse hetmańskie rozesłałem do wszystkich chorągwi, aby w gotowości do ruszenia za najpierwszym ordynansem hetmańskim były, tak, że jeden komputowy żołnierz w całej prowincji wielkopolskiej nie zostanie" raz kolejny stając się gwarantem ładu i bezpieczeństwa wewnętrznego w Rzeczypospolitej:

To Pogoń lądem szła Srzeniawa brzegiem

Płynęła, tłum zaś różny swym szeregiem

Idzie, ściągając na Trybunał nowy

Aby w początkach swych nie podniósł głowy

Lecz co się dzieje z płochą tą wyprawą

Gdy istny żołnierz z miną stanie żwawą

Prędzej zajęców wszyscy uciekali

By ich hetmańscy w troki nie pobrali.

Tak dla tych Chwała dla tamtych wstyd wieczny

Prawo w całości Trybunał bezpieczny?

Dalej, jak czytamy w satyrze, dzięki Branickiemu powołana zostaje komisja dubieńska i całkowicie udaremnione działania spiskowców. W Epilogu:

Tryumfuj w Twoim Ojczyzno Hetmanie

Już skutek w Panu ma Jego staranie

Już król łaskawy skasował racją

Śmiertelnej kary na Ordynacją [...]

Zgoła próba tej w Polszcze awantury

Tysięczni światu odkryła figury

Które niech dalszych światłem będą prywat

W Ordynacji Król z Hetmanem Vivat, Vivat, Vivat!

${ }^{6}$ AGAD, APzŁ, sygn. 1833. 2. Por. „Rosja a Piotr i Jan Sapiehowie w dobie kryzysu ostrogskiego". 37.

${ }^{7}$ Podobny opis jest również w Eysej radzie kolbuszowskiej (AGAD, Zbiór Anny z Potockich Ksawerowej Branickiej, sygn. 469). Król rozkazuje: „Zażyjże swego ty Wielki Hetmanie, Prawa na prawa przez nich przełamanie, A jeżeli trzeba by więcej Wojsk było, Dam Moich Sasów by praw nie ubyło”. Hetman wykonuje rozkaz: „Pogoń szła lądem Szreniawą Towary, W Pogoń za nimi szli po tym tatary, I tak się stało z Piotrkowską wyprawą, Którzy do Boju z Imprezą szli krwawą, prędzej zającom nazad uciekali, By się w gonitwie złapać im nie dali, Tobie to Królu zwycięstwo dać mamy, Bo cię za Pana Stany Polskie znamy, Tobie y Hetman z Rycerstwem się ściele, Y Senat z Tobą Tryumfuje śmiele.” Trudno się jednak oprzeć wrażeniu, że w tej wersji, przy zaakcentowaniu zasług Branickiego, sukces bardziej jest efektem wysiłku całej wspólnoty, a nie jednostki. 
Wbrew pozorom nie wydaje się zresztą, aby obraz z prezentowanych w niniejszym tekście satyr był całkowicie nieprawdziwy. Mamy bowiem archiwalne ślady strachu przed negatywnymi konsekwencjami transakcji kolbuszowskiej wśród szlachty i magnaterii. J. Kownacki ostrzegał Eustachego Potockiego, że zamęt powstały w związku z transakcją kolbuszowską może doprowadzić do ,jakiej rewolucji"». Konfederacji południowych województw zawiązanej na znak sprzeciwu wobec transakcji obawiał się natomiast biskup krakowski Andrzej Stanisław Załuski (Wyszomirska 80).

Jak pisze Anna Oleńska, Arrotino najczęściej interpretowany był jako „poddany ujawniający spisek przeciwko państwu, podsłuchany podczas wykonywania swej pracy" (Jan Klemens Branicki 17). W białostockim przypadku, w świetle cytowanej powyżej Sceny tragiczno-komicznej, Branicki najpierw jest „kochającym synem" ojczyzny, potem zaś lojalnym poddanym króla, któremu donosi o spisku przeciwko Rzeczypospolitej. Dodać należy: zawiązanym w tejże Rzeczypospolitej. To stwierdzenie, pomimo iż wydaje się banalne, jest niezbędne, jeśli mamy w pamięci napisane kilka lat temu przez Tomasza Dziubeckiego zdanie: „Trudno przypuszczać, iż Rotator białostocki miał pokazywać, że w apartamentach hetmana zawiązuje się jakiś spisek" (Dziubecki, Programy symboliczne 91).

Warto dodać, że motyw współdziałania hetmana z królem rozwinięty został w dekoracjach zdobiących stoły podczas imienin, drugiego imienia, Jana Klemensa Branickiego, w czasie Trybunału w Piotrkowie, 19 listopada 1756 r. (por. Gombin 151). Nawiązywały one do motywu Gigantomachii:

[...] na cukrach zaś misternie akkomodowanych te inskrypcye były:

Jako świat Polski widzi Klemensa męstwo,

Tak przyczyna razem z ludzkich serc Jego zwycięstwo.

Niech przy Jowiszu Orzeł grzmot, pioruny głosi,

Nam łaski Gryff Branickich od Tronu przynosi. (Kuryer Polski t. 176, 1756)

W świetle powyższych rozważań sugestie Oleńskiej, łączące powstanie Rotatora - Arrotina, z konfliktem o ordynację ostrogską, wydają się całkowicie uzasadnione i nie powinny budzić wątpliwości. Podkreślić należy wyjątkowość rzeźby - wykonana była z najcenniejszego w Białymstoku białego marmuru, co może świadczyć, że odnosiła się bezpośrednio do Hetmana.

W kontekście sporu o ordynację ostrogską rozpatrywać można nie tylko samego Rotatora, ale także pałacowy kontekst, w jakim się znalazł. Na piętrze,

${ }^{8}$ J. Kownacki do E. Potockiego 15 III 1754 z Dębin, Archiwum Państwowe na Wawelu, Archiwum Krzeszowickie Potockich, rkps 3214, cyt. za: Wyszomirska 180. 
w apartamencie paradnym, wisiały portrety Augusta III i Marii Józefy, był to więc symboliczny obraz Rzeczypospolitej ${ }^{9}$. To właśnie stamtąd znajdujący się na parterze Rotator usłyszał o spisku. Być może ze sprawą ostrogską wiązać należałoby Herkulesy wyrzeźbione przez Jana Chryzostoma Redlera, a ustawione na dziedzińcowych pylonach w 1758 r. (por. Oleńska, „Wątki heroiczne” 253). Heros ze smokiem mógłby oznaczać zwycięstwo hetmana w pierwszym etapie konfliktu, a heros z hydrą - nieustanne odżywanie konfliktu. Pamiętać należy, że na tympanonie ryzalitu elewacji frontowej pałacu eksponowany był Herkules zastępujący Atlasa (por. Nieciecki, Polski Wersal passim). Sprawy te wymagają zresztą dalszych, szczegółowych badań.

W Scenie tragiczno-komicznej Branicki ukazany został jako zwycięski wódz, którego militarna interwencja zapobiega wojnie domowej. Przy tym wątku warto się jeszcze zatrzymać. W publicystyce dotyczącej ordynacji ostrogskiej jest bowiem jeszcze jeden istotny wątek związany z Janem Klemensem Branickim, na który warto tu zwrócić uwagę.

W rękopiśmiennej Kopii listu pewnego przyjaciela względem podziału Ordynacyi Ostrogskiey ad praesens uczynionego od szczodrze kochajacego Oyczyzne czytamy:

Do obrony Ukrainy aby 600 ludzi od Ordynata Ostrogskiego naznaczonych pod komendę JW Hetmana granic ukraińskich pilnowali" [...] jeżeli Rzplita na te działy patrzyć będzie y swego Prawa wyraźnego zamilczy, to tym samym zda się disimulari y nie pretendować wyprawy 600 ludzi przez pierwszego Xcia Ordynata naznaczonych, ale bez wątpienia nie zamilczy podobno zażyć swego prawa y władzy zgoła tym podziałom prywatnym desuper nie zabiegną y JW JM Pan Hetman WK prawdziwy w żarliwości o dobro pospolite owego sławnego hetmana Czarnieckiego krwią y dzielnością sukcesor przy obronie tej ordynacji nie ustanie, trzeba się mocno obawiać wszelkich rozruchów y zamieszania ukochanej Ojczyźnie naszej dosyć temi domowemi Ojczyzny scysjami y kłótniami skołatanej [... $]^{10}$.

Problem owych 600 żołnierzy, których miała wystawić ordynacja ostrogska, był jednym z najczęściej pojawiających się argumentów przeciwko jej podziałowi, którego konsekwencją miało być zaprzestanie wystawiania tegoż wojska, co miało

\footnotetext{
${ }^{9}$ O tych pracach por. Nieciecki, „Koleje życia Antoniego Herliczki” 264.

${ }^{10}$ AGAD, Zbiór Branickich z Suchej, sygn. 109/131, Kopia listu pewnego przyjaciela względem podziału Ordynacyi Ostrogskiey ad praesens uzcynionego od szczodrze kochajacego Oyczyznę. Manuscripta anni 1754.
} 
mieć wpływ na zmniejszenie bezpieczeństwa Rzeczypospolitej ${ }^{11}$. W cytowanym tu XVIII-wiecznym tekście publicystycznym mamy, jak się zdaje, jednak dalej idące związki przyczynowo-skutkowe. Z Kopii listu pewnego przyjaciela... wynika bowiem, iż Branicki był zobowiązany do interwencji w sprawie ostrogskiej nie tylko z militarnego punktu widzenia, jako hetman, gdyż owych 600 żołnierzy podlegało właśnie jurysdykcji hetmańskiej. Stąd też dodatkowe porównania z Czarnieckim, który był nie tylko antenatem Branickiego i swoistym przodkiem na urzędzie hetmańskim, ale w związku z tym także, można powiedzieć, przodkiem jako dowódca wojsk wystawionych przez ordynację ostrogską. Przy ówczesnym sposobie myślenia i przekonaniu, że cały splendor przodków pozostaje na zawsze w rodzinie ${ }^{12}$, ma to wyjątkowe znaczenie, a problem, czy chodzi o buławę wielką czy polną (która była szczytem kariery Czarnieckiego), nie miał w tym myśleniu większego znaczenia, gdyż w cytowanym rękopisie nie sprecyzowano, któremu hetmanowi podlegało to wojsko. Warto przy tym pamiętać, że Stefan Czarniecki walczył z Kozakami i szlacheckimi konfederatami (por. Kersten 543), czyli i w tym aspekcie Branicki musiał zapewne być dla współczesnych, niczym jego hetmański antecesor, kontynuatorem XVII-wiecznych tradycji pacyfikowania konfliktów wewnętrznych.

Stefan Czarniecki w kręgu Branickiego to bohater niezwykle popularny, według inwentarza z 1772 r. w pałacu białostockim były trzy rzeźbiarskie popiersia i jeden obraz przedstawiające XVII-wiecznego hetmana (Oleńska, Jan Klemens Branicki 234-235). W roku 1761 Jan Klemens ufundował w Tykocinie pomnik Czarnieckiego, ustawiony w 1763 roku (Gajewski). Na pomnikowej inskrypcji, w polskim tłumaczeniu, czytamy między innymi:

Postawił pomnik jako należną pamiątkę bohater sławnemu bohaterowi, wódz - wodzowi. I powie, że dla obywatela najwyższą chwałą jest zasłużyć na pochwały swoich królów i ojczyzny. Niech umilkną prywatne pochwały i miejsca ustąpią. Oto wszak król i ojczyzna męża wielkiego już sławią. (Cyt. za: Oleńska, Jan Klemens Branicki 362)

W rzeczywistości Branicki nie miał poważniejszych zasług jako hetman, w historiografii określano go nawet, jako tego, co „prochu nie wąchał” (Konopczyński, „Branicki Jan Klemens”404; Oleńska, „Wątki heroiczne” 261). Dopiero z perspektywy sporu o ordynację ostrogską, i wyżej zaprezentowanych opinii, pamięć Stefana Czarnieckiego w kręgu Branickiego zyskiwała szczególny wymiar.

${ }^{11}$ Por. na przykład: Konopczyński, „Ostrogska ordynacja” 795; Czeppe, Kamaryla Pana z Dukli passim; Długosz 25.

${ }^{12} \mathrm{O}$ tym przeświadczeniu por. Górska 112. 


\section{BIBLIOGRAFIA}

ŹRÓDŁA

\section{a) niepublikowane}

Archiwum Główne Akt Dawnych, Archiwum Potockich z Łańcuta, sygn. 1833, list Piotra Pawła Sapiehy do Stanisława Lubomirskiego z 22 III 1754 r.

Archiwum Główne Akt Dawnych, Zbiór Anny z Potockich Ksawerowej Branickiej, sygn. 469, Łysa rada kolbuszowska.

Archiwum Główne Akt Dawnych, Zbiór Branickich z Suchej, sygn. 109/131, Kopia listu pewnego przyjaciela względem podziału Ordynacyi Ostrogskiey ad praesens uczynionego od szczodrze kochającego Oyczyznę. Manuscripta anni 1754.

Biblioteka Jagiellońska, rkps 1808 IV. Scena tragiczno-komiczna na publicznym światu polskiego theatrum pokazana wyrok niewinnej śmierci i cudownego po tym uwolnienie ordynacyi ostrogskiej prezentująca Ojczystą Muzą przez jednego ze spektatorów opisana.

Biblioteka Poznańskiego Towarzystwa Przyjaciół Nauk, sygn. 360, Łysa rada kolbuszowska. Dialog satyryczny wierszem w sprawie ordynacji ostrogskiej, rozwiązanej przez Janusza Aleksandra Sanguszkę.

\section{b) publikowane}

Matuszewicz, Marcin. Diariusz życia mego, t. I. Wstęp Bogdan Królikowski. Komentarz Zofia Zielińska, Państwowy Instytut Wydawniczy, 1986.

Kitowicz, Jędrzej. Pamiętniki, czyli Historia Polska. Wstęp Przemysława Matuszewska. Komentarz Zofia Lewinówna. Państwowy Instytut Wydawniczy, 2005.

\section{OPRACOWANIA}

Buchwald-Pelcowa, Paulina. Satyra czasów saskich, Ossolineum, 1969.

Czeppe, Maria. Kamaryla Pana z Dukli. Kształtowanie się obozu politycznego Jerzego Augusta Mniszcha 1750-1763, Wydawnictwo Neriton, 1998.

Długosz, Józef. „Transakcja kolbuszowska 1753 i jej skutki społeczno-polityczne”. Z dziejów kryzysu państwowości polskiej u schyłku XVII wieku $i$ w XVIII wieku. Postulaty badawcze, red. Aleksandra Skrzypietz, Jacek Kurek, Przedsiębiorstwo Produkcyjno-Handlowo-Usługowe „Rococo”, 1997, ss. 25-26.

Dziubecki, Tomasz. „Rotator w Wersalu Podlaskim”. Artyści włoscy w Polsce XV-XVIII wiek, Wydawnictwo DiG, 2004, ss. 657-660.

Dziubecki, Tomasz. Programy symboliczne i funkcje ceremonialne rezydencji magnackich Puławy-Białystok-Radzyń Podlaski-Lubartów w latach 1750-1760, Muzeum Pałac w Wilanowie, 2010.

Gajewski, Jacek. „Pomnik Czarnieckiego w Tykocinie - jego autor i wykonawca: Coudray i Redler?". Laudator temporis acti. Studia z dziejów sztuki i kultury ofiarowane Księdzu 
Doktorowi Janowi Niecieckiemu w 65. rocznice urodzin, red. Irena Rolska, Krzysztof Gombin, Krzysztof Przylicki, Wydawnictwo KUL, 2015, ss. 183-217.

Gombin, Krzysztof. Trybunat Koronny. Ceremoniat i sztuka. Wydawnictwo KUL, 2013.

Górska, Magdalena. „Dwór i familia. Wizerunek magnaterii w dekoracji okazjonalnej XVIII stulecia”. Dwory magnackie w XVIII wieku. Rola i znaczenie kulturowe, red. Teresa Kostkiewiczowa, Agata Roćko, Wydawnictwo DiG, 2005, ss. 111-136.

Kersten, Adam. Stefan Czarniecki 1599-1665, Wydawnictwo UMCS, 2006.

Konopczyński, Władysław. „Ostrogska ordynacja”. Wielka Encyklopedia Powszechna Ilustrowana, seria II, t. V-VI, Nakład i druk S. Sikorski, 1908, ss. 793-797.

Konopczyński, Władysław. Polska $w$ dobie wojny siedmioletniej, t. I, W.L. Anczyc, 1909.

Konopczyński, Władysław. „Branicki Jan Klemens”. Polski Słownik Biograficzny, t. 2, Polska Akademia Umiejętności, 1936, ss. 404-407.

Nieciecki, Jan. Polski Wersal, Wydawnictwo Łuk, 1998.

Nieciecki, Jan. „Koleje życia Antoniego Herliczki malarza polskiego XVIII wieku”. Roczniki Humanistyczne, t. 54, z. 4, 2006, ss. 225-290.

Oleńska, Anna. „Wątki heroiczne w programie dekoracji białostockiej rezydencji Jana Klemensa Branickiego". Dwory magnackie w XVIII wieku. Rola i znaczenie kulturowe, red. Teresa Kostkiewiczowa, Agata Roćko, Wydawnictwo DiG, ss. 245-262.

Oleńska, Anna. „Sekretne treści pałacu w Białymstoku. O figurze Rotatora na klatce schodowej". Artyści włoscy w Polsce XV-XVIII wiek. Wydawnictwo DiG, 2004, ss. 643-656.

Oleńska, Anna. Jan Klemens Branicki ,,sarmata nowoczesny”. Kreowanie wizerunku poprzez sztuke, Instytut Sztuki PAN, 2011.

Szwaciński, Tomasz. „Rosja a Piotr i Jan Sapiehowie w dobie kryzysu ostrogskiego”. Kwartalnik Historyczny, t. 119, nr 1, 2012, ss. 31-65.

Wyszomirska, Monika. Między obrona wolności a naprawa państwa. Rzeczpospolita jako przedmiot polemik politycznych $w$ dobie panowania Augusta III (1734-1763), Wydawnictwo DiG, 2009.

\title{
O REMINISCENCJACH KONFLIKTU O ORDYNACJĘ OSTROGSKĄ W SZTUCE KRĘGU JANA KLEMENSA BRANICKIEGO
}

\author{
Streszczenie
}

Rzeźba z klatki schodowej białostockiego pałacu Jana Klemensa Branickiego, najczęściej określana jako Rotator („Obracający się”) albo Arrotino („Ostrzący nóż”), według nowszych badań mogła przedstawiać jednego z rzymskich bohaterów (Windycjusza, Milichusa, czy też Feniusza Rufusa), który podczas wykonywania swojej pracy podsłuchał spiskowców i tym samym udaremnił ich knowania. Miała to być aluzja do roli hetmana Jana Klemensa Branickiego (fundatora rzeźby) we współczesnych mu wydarzeniach - konfliktu o ordynację ostrogską. Tezę tę potwierdzają rękopiśmienne satyry, powstałe w związku ze sporem o ordynację (Lysa rada kolbuszowska oraz Scena tragiczno- 
-komiczna...), których Branicki jest jednym z głównych bohaterów. W Scenie tragiczno-komicznej podział ordynacji przedstawiony został jako spisek przeciwko Rzeczypospolitej, który odkrył i zbrojnie spacyfikował hetman Branicki. Działania te rozpoczął samodzielnie podczas nieobecności w Rzeczypospolitej króla, stając się najważniejszą osobą w kraju i jego mężem opatrznościowym, a dokończył, współdziałając z powracającym monarchą. Białostocki Rotator może więc być odnoszony do Branickiego, ukochanego syna ojczyzny, lojalnego poddanego oraz wielkiego wodza, który zapobiegł wojnie domowej. W publicystyce związanej ze sporem o ordynację ostrogską Branicki porównywany był także do swego przodka - hetmana Stefana Czarnieckiego, gdyż podobie jak on miał uchronić Rzeczpospolitą od wewnętrznego konfliktu. Stefan Czarniecki to bohater w Białymstoku bardzo popularny, często przedstawiany na zamawianych przez Branickiego rzeźbach i obrazach. W rzeczywistości Branicki nie miał poważniejszych zasług jako hetman i dopiero z perspektywy sporu o ordynację ostrogską i kreowania go wówczas na wielkiego wodza i męża opatrznościowego kultywowanie pamięci o Stefanie Czarnieckim zyskiwało szczególny wymiar.

Słowa kluczowe: ordynacja ostrogska; Jan Klemens Branicki; pałac w Białymstoku; białostocki Rotator.

\section{THE REMINISCENCES OF THE CONFLICT OVER THE OSTROGSKI ORDINATION IN THE ART OF JAN KLEMENS BRANICKI'S CIRCLE}

\section{Sum mary}

According to more recent research, the sculpture from the staircase of Jan Klemens Branicki's palace in Bialystok, most often referred to as Rotator ("Rotating") or Arrotino ("Knife Grinder") may have depicted one of the Roman heroes (Vindictius, Milichus or Fenius Rufus) who, while doing his job, overheard the conspirators and thus thwarted their scheming. It was supposed to be an allusion to the role of Hetman Jan Klemens Branicki (the founder of the sculpture) in the contemporary events the conflict over the Ostrogski Ordination. This thesis is confirmed by handwritten satires, created in connection with the dispute over the ordination (Lysa rada kolbuszowska [The Bald Council of Kolbuszowa] and Scena tragiczno-komiczna na... [A Tragicomical Scene]), of which Branicki is one of the main characters. In Scena tragiczno-komiczna na, the division of the ordination was presented as a conspiracy against the Polish-Lithuanian Commonwealth, which was discovered and pacified by Hetman Branicki and his army. He started these actions on his own during the king's absence, becoming the most important person in the country and the man of the moment, and then completed them in cooperation with the returning monarch. Thus, the Rotator from Białystok can be referred to Branicki, the beloved Polish son, a loyal subject and a great military leader who prevented civil war. In the journalistic texts related to the dispute over the Ostrogski Ordination, Branicki was also compared to his ancestor, Hetman Stefan Czarniecki, as similarly to him, he would prevent the Polish-Lithuanian Commonwealth from the internal conflict. Stefan Czarniecki is a very popular character in Białystok, often depicted in sculptures and paintings ordered by Branicki. In fact, Branicki did not have any 
serious merits as a hetman; it was only from the perspective of the dispute over the ordination and his portrayal as a great leader and the man of the moment that the cultivation of the memory of Stefan Czarniecki gained a special importance.

Keywords: Ostrogski Ordination; Jan Klemens Branicki; Palace in Białystok; Rotator of Białystok.

Translated by Rafat Augustyn 